\title{
Recenzja
}

\section{Przemysław Osóbka, System konstytucyjny Bośni i Hercegowiny, Wydawnictwo Sejmowe, Warszawa 2011, ss. 76}

Jedną z najnowszych publikacji Wydawnictwa Sejmowego jest książka Przemysława Osóbki System konstytucyjny Bośni i Hercegowiny, która została opublikowana w ramach serii wydawniczej „Systemy konstytucyjne państw świata”. Warto na nią zwrócić uwagę, gdyż stanowi jedno z nielicznych na polskim rynku opracowań poświęconych rozwiązaniom ustrojowym przyjętym w tym stosunkowo młodym państwie. Owszem, można wskazać szereg książek, które dotyczą w całości lub w znacznej części Bośni i Hercegowinie (autorstwa W. Walkiewicza, M. Waldenberga, M. Tantego i innych), ale przede wszystkim odnoszą się do czasu krwawego konfliktu zbrojnego z lat 1992-1995 i jego skutków. Jak zresztą zauważa sam P. Osóbka, „Na najnowszych dziejach Bośni i Hercegowiny najpoważniejsze piętno odcisnęła wojna” (s. 5). Właściwie za jedyną pozycję, która do momentu wydania omawianej książki poświęcona była analizie ustroju tej postjugosłowiańskiej republiki, uznać należy monografię przygotowaną pod redakcją M. Gniazdowskiego: Europejski protektorat? Bośnia i Hercegowina w perspektywie środkowoeuropejskiej (Warszawa 2008). Ponadto częściowo omawianą problematykę, ale $\mathrm{w}$ kontekście innych państw powstałych po rozpadzie SFRJ, poruszali m.in. J. Wojnicki (Proces instytucjonalizacji przemian ustrojowych w państwach postjugosłowiańskich, Pułtusk 2007) oraz E. Bujwid-Kurek (Państwa pojugosłowiańskie. Szkice politologiczne, Kraków 2008). Trudno zatem mówić o wyczerpujących opracowaniach odnoszących się do systemu konstytucyjnego Bośni i Hercegowiny.

Biorąc pod uwagę wskazany powyżej niedobór polskiej literatury, z tym większym zainteresowaniem można było oczekiwać ukazania się książki autorstwa P. Osóbki. Jest on zresztą autorem innej pozycji, opublikowanej nakładem Wydawnictwa Sejmowego: Parlament Bośni i Hercegowiny (Warszawa 2010). System konstytucyjny Bośni i Hercegowiny oparty jest na identycznej konstrukcji jak wcześniejsze pozycje w tej serii wydawniczej. 
Nie jest to zatem praca nadmiernie obszerna, gdyż liczy 76 stron. Podzielona została na czternaście rozdziałów, zawiera również wstęp, aneks oraz spis wybranej literatury. Układ poszczególnych części jest logiczny i uzasadniony. Autor rozpoczyna od omówienia rysu historycznego konstytucjonalizmu Bośni i Hercegowinie (rozdział I), aby poprzez uwarunkowania i tryb uchwalenia obowiązującej konstytucji (rozdział II) przejść do analizy konkretnych rozwiązań ustrojowych. Omówione zostały konstytucyjne podstawy ustroju państwa (rozdział III) oraz system praw i wolności obywatelskich (rozdział IV). W dalszej kolejności P. Osóbka przedstawił założenia systemu wyborczego i kształt sceny partyjnej (rozdział V), a także strukturę naczelnych władz państwa (rozdział VI). Rozwinięcie omówionych w tej ostatniej części zagadnień można znaleźć w rozdziałach poświęconych głowie państwa (VII), parlamentowi (VIII), rządowi i administracji (IX) oraz systemowi rządów (XI). Autor przeanalizował także kwestie związane z ustawodawstwem (rozdział X), sądownictwem i ochroną praw obywatelskich (rozdział XII), strukturze terytorialnej (rozdział XIII) oraz ze stanami nadzwyczajnymi (rozdział XIV).

Bez wątpienia system konstytucyjny Bośni i Hercegowiny należy do najbardziej skomplikowanych spośród istniejących we współczesnym świecie. Wielokrotnie P. Osóbka wskazuje na jego specyfikę i niespotykane gdzie indziej rozwiązania. Ich genezy należy szukać w porozumieniu pokojowym, które parafowano w amerykańskim Dayton w listopadzie 1995 r., a którego częścią (a dokładniej aneksem nr 4) jest tekst obowiązującej konstytucji. Jak podkreśla autor, paradoksem jest to, że zaakceptowali je politycy, którzy wcześniej sami doprowadzili do wojny, a którzy w momencie podpisywania porozumienia byli przekonani o jego tymczasowości (s. 13). Wielokrotnie w pracy podkreślona została także rola wspólnoty międzynarodowej, której Wysoki Przedstawiciel posiada niezwykle szerokie kompetencje, umożliwiające m.in. odegranie decydującej roli w procesie stanowienia prawa czy odwołanie każdego polityka, nawet zajmującego najwyższe stanowiska państwowe, łącznie z funkcją w kolegialnej głowie państwa (s. 14).

W rozdziałach poświęconych poszczególnym organom władzy państwowej autor stanął przed trudnym zadaniem przeanalizowania systemu, który ze względu na stopień swojego skomplikowania musi zostać uznany za co najmniej specyficzny. U jego podstaw leży założenie, iż w Bośni i Hercegowinie najważniejsze jest zapewnienie równej pozycji ustrojowej trzech na- 
rodów konstytutywnych: Bośniaków, Serbów i Chorwatów. Związane z tym jest ścisłe przestrzeganie parytetów etnicznych, co pozwala sądzić, iż - w połączeniu $\mathrm{z}$ innymi cechami systemu politycznego - w tym państwie zastosowano rozwiązania typowe dla koncepcji demokracji konsocjonalnej, której autorem jest holenderski politolog A. Lijphart (s. 56). Jest to zresztą opinia, z którą zgadza się większość autorów zarówno bośniacko-hercegowińskich, jak i zagranicznych ${ }^{1}$. P. Osóbka wskazał więc m.in. na specyfikę trzyosobowej głowy państwa, czyli Prezydium Bośni i Hercegowiny (s. 35-39), etnicznie zdeterminowany skład Izby Narodów jako izby wyższej Skupsztiny Parlamentarnej (s. 40-46), jak też na inne przykłady instytucji i organów władzy, których obsada w największym stopniu uwarunkowana jest koniecznością zachowania właściwych proporcji między przedstawicielami trzech głównych narodów oraz uzyskaniem konsensusu przy podejmowaniu decyzji. Niestety, przestrzeganie powyższych zasad działa niekorzystnie zarówno na szybkość procesu decyzyjnego (możliwość blokowania), jak i dyskryminację członków innych grup narodowościowych. Autor słusznie zauważa, że wszechobecność i dominująca rola czynnika etnicznego powoduje, iż „System wyborczy Bośni i Hercegowiny jest obarczony wieloma niedostatkami” (s. 30).

Doceniając trud autora, włożony w przeanalizowanie i omówienie niezwykle skomplikowanego systemu konstytucyjnego, należy wskazać pewne błędy i uchybienia. Mają one charakter zarówno edytorski, jak i merytoryczny. Do pierwszego rodzaju można zaliczyć niekonsekwencję w formie przypisów, które odnoszą się do prac pod redakcją. W niektórych przypadkach są wymienieni tylko redaktorzy, bez wskazania faktycznych autorów rozdziałów (np. na s. 11: R. Grabowski, S. Grabowska (red.), Zasady zmiany konstytucji w państwach europejskich, Warszawa 2008, s. 56), a w innych przypisy mają prawidłową formę (również s. 11: W. Stanisławski, Źródła kryzysu politycznego w Bośni i Hercegowinie, [w:] Europejski protektorat? Bośnia i Hercegowina w perspektywie środkowoeuropejskiej, pod red. M. Gniazdowskiego, Warszawa 2008, s. 36) ${ }^{2}$.

1 Zob. np.: M. Kasapović, Bosna i Hercegovina - podijeljeno društvo i nestabilna država, Zagreb 2005; A. Mujkić, Ideološki problemi konsocijacijske demokratije u Bosni i Hercegovini, "Status” nr 13, 2008; R. Belloni, Peacebuilding and Consociational Electoral Engineering in Bosna and Herzegovina, „International Peacekeeping” nr 2, 2004.

2 Kilka stron dalej (s. 16) ta sama pozycja jest już przytoczona w następującej formie: M. Gniazdowski (red.), Europejski protektorat? Bośnia i Hercegowina w perspektywie środko- 
Jednak znacznie poważniejsze są błędy merytoryczne, które mogą wskazywać na niepełne rozeznanie autora w omawianym temacie. Na s. 19 znajduje się sformułowanie, że ustawa zasadnicza na szczeblu krajowym powierza - w ramach trójpodziału władzy - władzę sądowniczą Trybunałowi Konstytucyjnemu, Sądowi Bośni i Hercegowiny oraz sądom powszechnym. Problem polega na tym, że - po pierwsze - w żadnym artykule konstytucji nie dokonano expressis verbis takiego podziału, a po drugie, Sąd Bośni i Hercegowiny w ogóle nie jest w niej wymieniony. Ten organ powołał dopiero w 2000 r. Wysoki Przedstawiciel, a odpowiednią ustawę zatwierdzającą jego decyzję przyjął dwa lata później parlament ${ }^{3}$. Nie można się też zgodzić z P. Osóbką, że „Zgodnie z konstytucją, parytety etniczne mają zastosowanie przy obsadzie stanowisk w Trybunale Konstytucyjnym". Tymczasem jest to jeden z nielicznych organów w Bośni i Hercegowinie, przy powoływaniu którego ustawa zasadnicza nie narzuca żadnych wymogów co do przynależności etnicznej tych sędziów, którzy mają być wybrani spośród obywateli państwa (sześciu spośród dziewięciu - trzech musi pochodził spoza Bośni i Hercegowiny oraz krajów sąsiednich) ${ }^{4}$. W stosunku do organów sądowniczych błędna jest też informacja, że sędziów Trybunału Konstytucyjnego wybiera się na 5 lat bez możliwości ponownej elekcji (s. 61). Takie rozwiązanie konstytucja przewidywała tylko dla pierwszego składu, a w przypadku kolejnych sędziowie mogą pełnić swój mandat do 70. roku życia, bez wskazania długości kadencji (art.VI/1.c) $)^{5}$.

Nie do końca rację ma P. Osóbka pisząc, że w praktyce można dostrzec równoległe funkcjonowanie dwóch systemów partyjnych. Silne podziały etniczne powodują, że niemal zupełnie brak jest partii ponadetnicznych, przez co w Bośni i Hercegowinie można mówić o trzech niezależnych systemach partyjnych - bośniackim, serbskim i chorwackim. Ugrupowania rywalizują

woeuropejskiej, Warszawa 2008. Nie została podana w tym przypadku nawet strona, z której zaczerpnięto informacje.

3 Por.: N. Smailović, N. Keranović, Pravosudni sistem, [w:] Uvod u politički sistem Bosne i Hercegovine, pod red. S. Gavricia, D. Banovicia, C. Krausego, Sarajevo 2009.

4 Por.: M. N. Simonić, M. Simonić: Uloga Ustavnog suda BiH u odbrani i daljnjoj izgradnji evropskog identiteta u BiH, „Anali Pravnog fakulteta Univerziteta u Zenici” nr 7, 2011. Inną sprawą jest, że - mimo braku formalnych wymagań - i tak stanowiska sędziowskie obsadzane są według klucza etnicznego, jednak nie jest to skutek zastosowania przepisów prawa, a raczej efekt zwyczaju.

5 Tekst konstytucji dostępny na stronie Trybunału Konstytucyjnego: http://www. ccbh.ba/bos/article.php?pid=633\&kat=83\&pkat $=85,(01.09 .2011)$. 
o głosy wyborcze w ramach zamkniętych, homogenicznych grup, co prowadzi do swoistej „terytorializacji etnicznej”.

Błędy można znaleźć również $\mathrm{w}$ rozdziale poświęconym samorządowi terytorialnemu. Na s. 66 znajduje się sformułowanie, iż w ramach kompetencji rada gminy ma prawo wybierać burmistrza. Niestety, od dłuższego czasu jest to już nieaktualne, gdyż pierwsze wybory bezpośrednie tego organu władzy lokalnej zostały przeprowadzone w 2004 r. - wyjątkiem jest Mostar, gdzie ze względu na skomplikowaną strukturę etniczną wciąż jest dokonywana elekcja pośrednia7. Także nie do końca prawdziwa jest informacja ze s. 63, że stolicą Republiki Serbskiej, jednego z dwóch podmiotów składowych Bośni i Hercegowiny (drugim jest Federacja Bośni i Hercegowiny), jest Banja Luka. Owszem, znajdują się tam najważniejsze organy władzy tego podmiotu, ale zgodnie z art. 9 Konstytucji Republiki Serbskiej oficjalną stolicą jest Sarajewo ${ }^{8}$. Szkoda też, że autor nie wspomniał o wprowadzeniu do konstytucji Bośni i Hercegowiny w 2009 r. regulacji dotyczących Dystryktu Brčko, terytorium spornego między Republiką a Federacją 9 .

Odnosząc się z kolei do omówionej w rozdziale VIII procedury ustawodawczej, należy podkreślić, że zwykła większość jest niezwykle rzadko stosowana podczas głosowania w izbie niższej parlamentu (w przeciwieństwie do tego, co pisze P. Osóbka). Znacznie częściej i w ważniejszych sprawach wymagana jest specyficzna większość, która wymaga właściwej reprezentacji posłów z obu podmiotów państwa ${ }^{10}$.

Starając się podsumować pracę autorstwa P. Osóbki, można mieć mieszane odczucia. Z jednej strony bez wątpienia stanowi ważny wkład w literaturę przedmiotu, ze względu na znikomą liczbę pozycji traktujących o systemie politycznym Bośni i Hercegowiny. Z drugiej strony ma się jednak nieodparte wrażenie, że autor nie do końca poznał omawianą tematykę, na co wskazują dość liczne - niestety - błędy i nieścisłości, które w tego typu publikacji nie powinny się zdarzyć. Może to wynikać z braku dostępu do publikacji

\footnotetext{
$6 \quad$ N. Mujagić, Tihi govor Bosne, Sarajevo 2010, s. 103.

7 Por.: M. Pejanović, E. Sadiković, Lokalna i regionalna samouprava u Bosni i Hercegovini, Sarajevo/Zagreb 2010, s. 99-102.

8 Zob.: http://www.narodnaskupstinars.net/lat/pas/ustav.htm, (01.09.2011).

9 Amandman I na Ustav Bosne i Hercegovine, Službeni glasnik BiH, br. 25, 2009.

10 Por.: K. Trnka, Ustavno i poslovničko pozicioniranje procesa odlučivanja u Parlamentarnoj skupštini BiH, [w:] Proces odlučivanja u Parlamentarnoj skupštini Bosne i Hercegovine, pod red. I. Maricia, Sarajevo 2009, s. 43-44.
} 
wydanych na terenie tego państwa, gdyż załączona na końcu książki literatura opiera się przede wszystkim na źródłach polsko- i anglojęzycznych.

Krzysztof Krysieniel (Wyższa Szkoła Bankowa w Poznaniu Wydział Zamiejscowy w Chorzowie) 